\title{
Research on the Training Mode of Innovative Research Universities Undergraduate Financial Management
}

\author{
Jun ZHANG \\ Weifang University of Science and Technology \\ Shouguang,Weifang,Shandong, 262700 China
}

\begin{abstract}
According to the target about building undergraduate college financial management training, building training model, proposed measures to improve teaching model in terms of curriculum system and practicing teaching system, etc. to show the training and teaching mode effects.
\end{abstract}

Keywords- Universities; Financial Management; education; training mode

\section{INTRODUCTION}

Personnel training are the target for college students. College talent students not only know the basic knowledge related to the professional and basic skills, but also have engaged in operational ability and creativity relating to work. Therefore, the university undergraduate financial management training aim to adapt the needs of socialist modernization, cultivating all-round development, having solid financial management basic theory and professional knowledge, and having a strong awareness of practicing ability, and a certain sense of innovation, engaging all sectors of cooperating financial expertise students. In view of the above training objectives, specifically, the undergraduate college financial management professionals should have a basic knowledge and overall quality, professional knowledge and skills, ability and capacity foe development in three areas. In terms of basic knowledge and the overall quality, with good moral character, strong language expression, language and interpersonal communication skills, and be able to operate a computer skillfully and use the Internet and various financial software; and for the professional knowledge and skills, its aim is to have financial theoretical knowledge, management and other aspects of financial management methods and skills, and have the solid expertise in the industry, and can be able to work in the financial industry, with a strong ability to operate financial practices.

\section{IMPROVE THE FINANCIAL MANAGEMENT OF THE UNDERGRADUATE TEACHING TRAINING MODE}

We should base on the formulation and revision of personnel training programs in line with the teaching mode, and construct curriculum system is the core of personnel training programs, therefore, it is necessary to make the structure of knowledge, the ability to structure and construction as a main line, and break the traditional mode about" Public basic courses Basic Course + Courses +", to build "Platform + Module" curriculum.

A. The curriculums of "two platforms".

It is a platform for the general education courses. It emphasizes the integration of science and humanities education, and lays the foundation for quality education, including ideological and moral cultivation, English, mathematics, basic computer and other university general education courses. Features about these courses should be reflected in the training of basic knowledge and basic skills, students' ideological and political training, logical thinking and analytical skills, and improve their English and computer skills; the platform for the basic Courses is Stressed in the professional cross, integration, broadening the professional caliber to meet the needs of a number of professional directions, including economics, management science, statistics, economic law and other disciplines basic course. The purpose is to offer professional courses for students to lay a solid foundation, so that students can have the basic knowledge, basic theory and basic skills.

\section{B. Professional module curriculum and set of the professional courses.}

Professional module curriculum is different from the other professional financial management, which is a manifestation of the central features about the professional courses, including professional courses and professional electives. Professional courses includes the financial management, Intermediate Financial Accounting, Advanced Financial Accounting, Auditing and other courses; specialized electives, including tax planning, asset valuation, international financial and other courses. It particularly noted that, in the setting of college financial management courses, it is necessary to handle the convergence of curriculum content correctly, such as financial management and management accounting, cost accounting courses on the existence of some cross and duplicate content; industry module settings. On the basis of the curriculum system, we set module according to the student development and employment needs of different industries, students choose from enhancing students' ability to adapting to different sectors of the financial work, and increasing the employment rate and job satisfaction. The institutions choose modules for different industries according to their characteristics, for example, I belong to the school of engineering colleges who 
have an engineering background, according to the student's employment direction, and we set up the construction of enterprise financial management module and the power of enterprise financial management. In the mode of the constructing enterprise financial management module, we set the introduction to Civil Engineering, construction budget, construction enterprise financial management, accounting statements and other construction companies analyze elective courses; in the power of enterprise financial management module, we set the introductory electrical engineering, electric power enterprise financial management Thematic and other elective courses.

\section{PROBlEMS ABOUT FinANCIAL MANAGEMENT TRAINING MODE ON COLLEGE}

\section{A. objectives of education are not clear.}

Because the financial management is separated from the accounting, finance, and other professional courses out and its training objectives still have traces of the relevant professional, compared with those related professionals, its own characteristics is not obvious, today most colleges and universities are not prominent, they copy other colleges' aims to cultivate all-round development of accounting senior professionals, and have a solid theoretical basis and practical operation ability of senior professionals with high-level expertise locating the target, they are apparently general training objectives, the positioning is too high and The targeting errors lead students in the school under the unrealistic expectations, and overestimate their abilities, and they can not do the specific work starting from the grassroots level.

\section{B. curriculum systems are not perfect.}

because it is too conceptual abstract, and no difference to describe the university's financial management training objectives, it makes the system set up similar programs, and plus a lot of financial management which separates from the former university professional accounting, finance, finance in the curriculum, it does not get rid of old professional model. As a university professional financial management, it should be clear to improve the ability of students to obtain lectures, it is not enough to teach the theory, you must get through teaching practice courses, theoretical courses and practical courses should be given equal treatment. However, there are more the theoretical lessons than the actual teaching process. In addition, the course is lack of advanced and forward-looking, and due to updating slower, new situations and knowledge of modern science and technology, culture, and economic development can not be quick to add, it is resulting in the knowledge learned in the schools can not be accessed.

\section{C. teaching methods and means are backward.}

Currently, teaching methods follow the financial management professional teaching methods, which teacher talk consistently and students listen in quiet, this teaching method enables students to take notes in class, review the notes before examine, but when testing they completely forget, the learning effect is far from ideal; at the same time, teaching methods and teaching equipment is relatively backward, they still confined to blackboard chalk, and for the inadequate use for multimedia and Internet, even with the computer-assisted instruction,

Multimedia, information technology and other teaching methods, is just to reduce the amount of writing on the blackboard; students can not afford to mobilize the enthusiasm and passion, and can not be better to improve teaching efficiently. However, the actual teaching process is more significant than the practical lesson

\section{PROFESSIONAL FINANCIAL MANAGEMENT MEASURES FOR GOVERNING THE UNDERGRADUATE COLLEGES}

\section{A. Professional Practice Curriculum.}

Financial management is the subject of financial funding, investment and income distribution and a series of campaign funds; it is an activity that has a strong management of capital operation, the professionalism and skills. The College Financial Management focuses more on management skills training. Therefore, in practicing, curriculum develops to balance accounting, the ability to manage, and the finance area. What Corresponding practical courses offer may include: computerized accounting and other financial software programs, financial analysis courses, financial management and curriculum design, corporate finance and curriculum design, audit case teaching (internal control), securities investment analysis. Thus, it laid a good foundation for the students' practical abilities in theory.

\section{B. To establish a multi-level financial management professional practicing curriculum.}

Scientific and rational design of financial management professional practicing course is to achieve a reliable guarantee for good teaching effect. Practical courses can not only help students consolidate students learning theoretical knowledge gradually, but also conducive to the knowledge comprehensive understanding of the system, it is to achieve system control and mastery goal. This paper argues that the practice of curriculum should include individual practice, integrated practice, social practice, graduation practice and graduation design form. Individual practice course is theoretical textbook chapters to test the unit, we organize courses according to the theory of progress, and this course includes the basic accounting, financial accounting, cost accounting, financial statement analysis, financial management, auditing, computerized accounting and other professional capacity test courses. Practical knowledge is an activity that related other courses together; the purpose is to achieve the ability of integrating the use of knowledge.

\section{C. training and hiring instructor who have a high quality}

Schools should encourage students to participate in the financial management of the various types of accounting professional titles, such as the ability CPA exam in order to improve "double" the proportion of teachers, and school can recommend that the teachers have more off-campus parttime jobs. Of course, these measures require schools to be 
realized under conditions of adequate teachers, and their teaching tasks can be mitigated. In addition, to encourage teachers to go out at the same time, school can also hire a high-school-level accounting staff that has a wealth of experience to the school to have a short-term training course, so it can teach students their vital work experience, and professional ability, this will greatly enhance the effectiveness of teaching practice of students.

\section{Training Mode about the CREative ThinkING}

To foster the philosophy internationalization and openness of educational. Schools learn from advanced international financial management professional education model, and use the international advanced financial management courses. Schools encourage teachers to use the bilingual language for teaching; classroom teaching should be quoted international financial management materials in a timely manner to introduce students the world's leading theoretical and cutting-edge course. With the rapid development of modern information technology, financial management should use the modern teaching methods, and by using multimedia teaching software and financial management software for financial management theory, online teaching can develop the distance education, and achieve the financial management teaching methods to be modern.

\section{A. emphasize the development of self-learning ability and creative ability.}

Because the financial management has social attributes, and with the changes in the environment of financial management adjusted, what students have learned in school may be eliminated so they need to acquire new knowledge through self-study and other ways; at the same time due to the actual situation of the various units of the different financial management, students need to adapt to the special circumstances of different enterprises, and must have a strong ability to adapt, but this capability is built On the basis of self-learning ability and creative ability above. Only one person has self-learning ability and ability to innovate things they can continue to learn new knowledge, and solve new situations encountered in practice. In the process of teaching students should self-study, self-analysis and solve problems, to develop their independent learning and innovation ability, students can learn or think some teaching content or problem, if taught by teachers, it will not only takes up teaching time, but also make the students lose the opportunity to exercise studying independently.

B. emphases on financial management practice teaching. Financial management is a practical professional expertise,

Service Management Graduates must have a strong practical ability to go to work in the position and adapt to the working environment quickly, therefore, practical teaching financial management can not be ignored, financial management practices including former teaching specific financial management experiments and graduation internships internship. Schools should strengthen financial management laboratory building. Whether it is teaching the required information or the process they all should be adequately addressed by simulation so that students can practice what they have learned to validate and consolidate, and can use a variety of learned knowledge to solve practical problems, thereby improving comprehensive analysis of the problems and their ability to solve problems.

\section{CONCLUSIONS}

In terms of professional training is no mature model for reference, many colleges and universities ignore the particularity of its students, and copy the professional training programs and teaching model, it did not form its own characteristics, people who train in the school lack of competitive advantage, and barriers significantly higher than the general undergraduate institutions, and the design characteristics of the training program, it is the only way to meet the social needs of the culture of high-quality professionals. In this paper, we make the professional financial management for the study, and find ways to improve problem specialty training programs.

\section{ACKNOWLEDGEMENTS}

Topic name "employment-oriented financial management undergraduate training model innovation research"

\section{References}

[1] Section Lin optimization practice and thinking Undergraduate Financial Management Training Program [J]. Journal of Hunan College of Finance and Economics, 2011,04: 69-72.

[2] In the Green Local Financial Management Major Comprehensive School and Talents [J] West Anhui University, 2009,06: 36-38.

[3] Source - pay college financial management practice teaching system [J] build Chengdu Institute of Public Administration, 2010, 01: 86-88.

[4] Victor Red improve college financial management professional training program [J] China Adult Education, 2013, 19: 184-185.

[5] Liuxian Shi thinking of Financial Management Major Construction in Chinese Universities [J] Science and Technology Information (academic), 2008,36: 350 .

[6] Wei Xiong Financial Management Undergraduate Education and Teaching [J] legal system and society, 2012, 33: 227-228. 